\title{
The Body, the Soul and the Animal Other
}

\author{
MAJA PASARIĆ \\ Institute of Ethnology and Folklore Research, Zagreb
}

\begin{abstract}
This paper deals with the concept of changes that human beings can undergo after death in relation to the transformative potential of the human body and everything it holds within, as it appears in different Croatian folk culture practices, such as folk songs and beliefs. The concept of the transformative potential of the human form involves different folk culture conceptions of the body, the soul and particular animalistic beliefs in which animals often assume the role of the Other. These issues will be discussed on two examples: folk songs that reveal the connection between water, fish and the dead as well as folk beliefs about a specific type of supernatural beings, werewolves.
\end{abstract}

Key words: body, soul, death, animal, transformations

Birth and death, body and soul, human and animal are known as sets of implacable oppositions that human life and culture is understood to be comprised of; as recognized and widely discussed within the scope of anthropological and ethnological thought and beyond. Nevertheless, the notions of the body and the soul are sometimes inextricably intertwined, and their relations are considered to be the counterparts of well-known divisions, such as materiality and the spirit. After all, the soul can be seen as the vital part of the body, and together they represent the completeness of a human being. Some South Slavic notions of the human body and soul are closely related to beliefs about nature, animals and different ideas about death and the afterlife. The core of human nature is questioned by death itself, in the face of which the divine and the animal characteristics that underlie humanity impart to human consciousness the knowledge that the human world is open-ended and unstable and that meanings attributed to the human physical form are not as solid as they appear (Davies 2005: 2; Shilling 2003: 155). Being a part of nature as well as culture, similarly but at the same time differently from human beings, animals often served as a means through which various liminal characteristics were expressed. For example, animals can affect the post-mortal transformation of the human form or even embody it. 
Ideas about the human soul taking the form of an animal or only translocating itself into one after the death of a human being have been recognized in different Slavic traditions. South Slavic folkloric notions about various forms and types of animal-like transformations of the human soul have been in the focus of interest of a number of authors (Marjanić 2004, 2011; Mencej 1995; Popov 2002). On the other hand, different theriomorphic traits or modes of transgressions between human and animal form are characteristic of a number of mythical and supernatural beings as well - identifiable through the specificities of their physical appearances or, for example, through the transformation of their soul during episodes of temporary death (Marjanić 2004, 2004a, 2012; Šešo 2007).

In this paper, the notion of the change of human form brought about by death will be discussed on the basis of two groups of examples ${ }^{1}$. It is perhaps true that connections between water and the dead along with human transformations into a fish ${ }^{2}$ have not been frequently drawn in Croatian ethnographic and folkloric sources. However, folk songs chosen for discussion illustrate interesting ichthyomorphic post-mortal changes of the human form, possibly linking this animal with the soul of the dead. The second group of examples refers to folk beliefs about a specific type of supernatural being, werewolves. It is transgression through death of a human being that is most often linked with the genealogy of werewolves, while beliefs and practices evolving around these mythical beings highlight different interrelations of animalistic notions and those related with the human body and soul.

These aspects of life/death, body/soul, and human/animal intersections will be investigated using Croatian ethnographic and folkloric sources, mainly from the late 19 th and the early 20th century - a time frame when such data have been extensively recorded. In the discussion examples from other South Slavic traditions will be mentioned as well. It is worth noting that the significant role that animals play in folk notions about death and afterlife are not a unique characteristic feature of Slavic traditions. Ideas similar to those discussed here could be investigated in a wider European and perhaps non-European context as well. Such examinations, however, lie outside the scope of the present article and are to be addressed as a theme of more extensive future research.

\footnotetext{
${ }^{1}$ Examples brought up for discussion - folk songs and beliefs - are different folkloristic genres. While such an approach might have its weaknesses it has been chosen in an attempt to reflect upon the wide distribution of animalistic notions, in particularly those related with death and the afterlife.

${ }^{2}$ It should be noted that human transformations into a fish as a folk literary motive can be found in a worldwide context (Thompson 1956: 23).
} 


\section{SWIMMING BODIES OR SOULS}

The notion of water as a sphere related to the dead, as the dividing line between the world of the living and the world of the dead or the path to the other world is present in different mythological traditions all over the world. In her book The meaning of water in old Slavic notions of life after death and in their customs at death Mirjam Mencej (1997) shows that such ideas, joined by the notion of water as a domain of afterlife itself, were known among different Slavic people as well. Slavic folk traditions also reveal a connection between water and the souls of the dead. As the bordering space between the earthly realm and the afterlife, water has also been thought of as a place where souls of the dead temporarily abide before they pass on to the other world and as the sphere in which unclean forces dwell (Vinogradova 2001: 87). Connections between the souls of the dead and water are often indicated by rather specific contexts, as we can learn from Slovenian folk literature examples mentioned by Mencej (1997: 66-68). For instance, the Slovenian folk song Tri pogubljene duše ${ }^{3}$ (Three lost souls) from Slovenska Bistrica mentions three souls swimming in water. However, as the song shows, the souls swimming in water are the souls of sinners who committed serious sins within a Christian context. Another interesting song is Neubogljiva hči, ukleta $v$ ribo (Disobedient daughter, cursed into a fish) which speaks about St. Lawrence who searched the world to find his sister cursed for disobedience by their mother and turned into a fish. The song has many variants, and apart from Slovenia it has also been recorded in Croatia under the title Sestra svetog Lovrenca (St. Lawrence's sister). In the song the sister in the shape of a fish is able to communicate with her brother informing him about her destiny.

I am your little sister

And my name is Anica

My mother has cursed me

With this icy water

And the swimming fish

She sent me to the water

On First Sunday of Lent

I did not want to listen to her

So she cursed me terribly

With this icy water,

And the swimming fish

\footnotetext{
${ }^{3}$ Štrekelj (1980/1: 429, n. 400).
} 
That I should swim in water

Until the Judgment of God. ${ }^{4}$

Let us note that the change from human to animal in the song Sestra svetog Lovrenca (St. Lawrence's sister) happens involuntarily as a result of a curse by way of punishment a young woman is turned into a fish and is condemned to this state of being until the Judgement day. Reflecting upon the song, Mencej (1997: 67) notes that St. Lawrence's sister turned into a fish can, in all probability, be referred to as the unclean dead, most likely because of the curse cast upon her. Whether it is about the souls of sinners as in the song Three lost souls or about the souls of the so-called unclean dead (those who were cursed or did not die of natural causes), it seems that the moral code and the code of ritual cleanliness links the dead with water as their dwelling place. In Slavic folk traditions, both categories of the dead are accorded special status; no longer being a part of the living world but unable to pass to the world of the dead, they rest in a liminal space between the living and the dead which is (in the cases above) expressed through water, a border between earthly life and the afterlife realm (ibid.).

Another song that mentions post-mortal change of a female character into a fish has been noted down among Croatians in the Hungarian Burgenland area. The song tells the story of two sisters, Mara and Ana, and their suitor Ivo who wanted to marry Mara, but the girls' mother gave him permission to marry Ana instead. Once they reached the sea, Ivo pushed Ana into the water. A year later Ivo went back to the mother telling her that Ana died giving birth to a son and asked her to let Mara be the child's nanny. Mara accompanies Ivo, but as they reach the sea Ana appears in the form of a fish, and talks to her sister who, realizing that Ana has turned into a fish, jumps into the sea herself.

A grapevine bore two bunches of grapes / a mother bore two daughters. / One was called Anica / the other was called Marica. / Ivo asked for Marica's hand, / her mother would not give her away. / When they came to the sea / Anka asked for water. / "Ivo get me some water / with your white hand!" / Ivo said to Anica: / "Stoop down, Ana, to the sea / and drink the cold water!" / Ana stooped down to the sea / Ivo pushed her into the sea. / When one year went by / Ivo went to see his mother-in-law. / The mother-in-law says to Ivo: / "Where is little Anica?" / Anica wove some linen, and bore a male child. / White linen is coarse / the male child is tearful. / So I came to get Marica, / let Marica be his nanny!" / The mother gave Marica away. / When they came

\footnotetext{
${ }^{4}$ Ja sam tvoja sestrica, / Po imenu Anica. / Mene majka proklela / S ovom mrzlom vodicom, / A plovućom ribicom / Slala mene na vodu / U kvaternu nedilju, / Nisam htila slušati / Ljuto mene proklela / S ovom mrzlom vodicom, / A plovućom ribicom: / Da u vodi plivala / Sve do suda božjega (Broz and Bosanac 1896: 21-23, n. 9; Starigrad near Jablanac Krajina).
} 
to the sea, / Marica asked for water: / "Ivo, get me some water / with your white hand!" / Ivo said to Marica: / "Stoop down, Mara, to the sea / and drink the cold water!" / Mara stooped down to the sea, / and in the sea there was a sturgeon. / Mara said to the fish / "Are you a real fish / or are you my little sister?" / "I am no sturgeon. / I am your real Anica, / your dear little sister." / When Marica heard this, / she jumped into the sea. / If there was no sister Anica / let there be no sister Marica! ${ }^{5}$

In this case the transformation into a fish can in all probability be linked with the way Ana died, being pushed into the water and therefore drowned. Similar motives have been recorded in the village Otok, in the Eastern part of Croatia. The song opens up with an image of a female individual named Ana who lost her life in the Danube. However, she was able to communicate by speaking with her female friends, and she sent a message to her father, informing him that different parts of her became parts of the Danube itself and therefore he should not drink the Danube water, scythe the Danube grass or eat the Danube fish.

Ana fell asleep on the bank of the Danube (Kirijo leližo!), The bank slipped, Ana fell. Ana says to her friends: Friends, tell my Dad not to drink the waters of the Danube: Danube waters - Ana's tears; Not to scythe the Danube grass: Danube grass - Ana's hair; Not to eat the Danube's fish: Danube's fish - Ana's bones. ${ }^{6}$

All three female characters from the above-mentioned songs can probably be related to the category of the unclean dead and their post-mortal manifestations, which, besides being confined to water, seem to be expressed through the transformations of their human form. Cursed or drowned, they dwell in the sphere between the world of the living and the world of the dead in the form of a fish or as different parts of their surrounding environ-

\footnotetext{
${ }^{5}$ B'jela loza dva grozda 'ranila, / majka je dvi ćeri od'ranila. / Jednoj je ime Anica, / drugoj je ime Marica. / Prosio Ivo Maricu, / ne da mu majka Maricu. / Kada su došli do morja / zaiska Anka vodicu. / "Dodaj mi Ivo, vodice / iz tvoje b'jele ručice!" / Govori Ivo Anici: / "Sagni se, Ano, na morje, / napi' se'ladne vodice!" / Sagne se Ana na morje, / turi je Ivo u morje. / Kada je prošla godina, / al' ide Ivo punici./ Govori Ivi punica: / "A 'di je seka Anica?" / "Anica platno navrgla, muško je čedo rodila. / B’jelo je platno tvrdivo, /muško je čedo plačljivo. / Pa sam doš’o po Maricu, / nek' bude Mara dadilja!” / Dala mu majka Maricu. / Kada su došli na morje, / zaiska Mara vodice: / "Dodaj mi Ivo, vodice / iz tvoje b’jele ručice!" / Govori Ivo Marici: / "Sagni se, Maro, na morje, / napi' se'ladne vodice!" / Sagne se Mara na morje, / a u morju riba moruna. / Govori Mara ribici / "Jesli li prava ribica/ ili si moja sestrica?" / "Ja nisam riba moruna / Ja sam ti prava Anixa, / tvoja mila sestrica." / Kada to čula Marica, / skočila Mara u morje./ "Kad nema sestre Anice, / nek nema ni sestre Marice!" (Franković 2004: 275-276).

${ }^{6}$ Zaspala Ana na brig Dunava (Kirijo leližo!), Brig se orinu, Anu zarinu. Govori Ana svojim drugama: Kažite druge mojemu dadi, Neka ne pije dunavske vode: Dunavska voda-Anina suza; Neka ne kosi dunavske trave: Dunavska trava - Anina kosa; Neka ne jede dunavske ribe: Dunavska riba - Anine kosti (Lovretić 1990: 322).
} 
ment. Although the word soul does not appear in these songs, in line with the animistic conceptions according to which at the time of their physical death a person continues to live on (Bandić 1980: 105-112), one might presume that it is the post-mortal manifestations of the souls that are referred to in the songs.

Nevertheless, the song from Otok speaks about different parts of the body undergoing changes after death. It seems that Ana's corporeality is divided and transformed into three different substances. Tears as the liquid substance of the human body literally become one with the river, indicating an eternal presence. The hair becomes the Danube grass, almost a permanent part of the river and its surroundings as well. According to South Slavic folk cultures' spatial division of a human body into binary oppositions, the hair belongs to the group of peripheral body parts ${ }^{7}$ that are thought to be more easily associated with the sphere of spirits and the chthonic world. At the same time, through the concepts of brushing and cutting, hair stands for continuous birth and dying and thus emerges as the symbol of eternal change (Radenković 1996: 25). The change of Ana's hair into the river grass can, in the context of the song, be linked with South Slavic folk notions of plants (especially low grass) acting as mediators in the communication between humans and the chthonic world, but also the belief that plants simultaneously embody change and constancy, disconnection and connection (ibid.: $197,189)$. In this way, changes happening to Ana's hair might be seen as the element that disconnects her from the world of the living and connects her with the sphere of post-mortal existence. What is also interesting is that the bones, a more solid substance in comparison to tears and hair, turn into a fish, an animal that can generally be understood as a symbol of transcendence, a messenger from the other world (Henderson 1973: 154) which is, in the South Slavic symbolic picture of the world, situated far away from humans on the vertical line of division and connected to the chthonic world (Radenković 1996: 85). All three transformations are in a way associated with movement - flowing, floating or swimming - as they also project implications of eternal movement, rebirth and maybe even a sense of immanence. Through the images of changes of specific bodily parts and functions into the river water, grass and fish, what is expressed is the manifestation of death, as well as a concretization of the time and space of post-mortal existence with which Ana becomes one. ${ }^{8}$ In the context of the song we can also think of post-mortal translocations of the vital force. According to South Slavic folk

\footnotetext{
${ }^{7}$ In South Slavic traditional culture the hair and nails are also viewed as the pars pro toto of a person with strong symbolic features (Radenković 1996: 25).

${ }^{8}$ Reading the song from Otok one can also recognize several elements of the feminization of water which can, according to Gilbert Durand (1991: 86), be traced back to the image of tears as the physiological signs of grief through which the infernal rivers and lakes have often been imagined, while the image of
} 
beliefs, the bodily soul seen as a kind of a life force located in different parts of the body can, along with other possible places, be located in the hair of a man or a woman (Petrović 1999: 62; Jovanović 2001: 178) or in their bones (the notion "his soul is roasted in his bones" (Zapekla [mu] se duša u kostima) has been recorded in Serbia and used when referring to a very old person that wouldn't die) (Karadžić 1965: 110). Therefore, in the framework of the song, one is tempted to think about the possibility that the life force once potentially located in Ana's hair and bones finds a new habitat in the river weed and in fish. After all, while looking at the song it should also be noted that Ana informs her father not to eat the Danube fish, drink the Danube waters or scythe the Danube grass, which might indicate that her vital force, her soul is now translocated into them, marking them as a taboo for a living person who should avoid being in contact with them.

As Suzana Marjanić (2004: 226-229) noted, phytometamorphosis, a soul's transformation into various plants, was not unknown in South Slavic folk traditions. Noting that the concept of phytometamorphosis can often be linked with folk songs about the innocently killed or dealing with unfortunate and persecuted lovers, Marjanić mentions the song Frane i Liana (Francis and Liana). In this song, after Francis's death a bouquet of marjoram grew on his body and a three-branched carnation on Liana's (Širola 1942: 83). Post-mortal translocations of the human's soul into animals are also well known in South Slavic folk traditions and have been thoroughly discussed by Marjanić as well (2004). According to South Slavic folk beliefs the soul most often translocates into a bird, a butterfly and a fly (Mencej 1995: 200). The soul's translocation into a mouse (Mencej ibid.: 204), a bee (Kulišić, Petrović and Pantelić 1970: 249), an ant (Vukanović 1986: 323) and a lizard (Zečević 1982: 11) have also been recorded. In the context of folk beliefs, the postmortal translocation of the human soul into a fish has not yet been identified. Still, implications of such possibilities may, perhaps, be encoded in folk songs previously discussed in the text.

Nevertheless, the song from Otok touches upon the transformational character of the human form. Whether approached through the contexts of corporeal transformations of the body and/or the reincarnation of the soul, it certainly reveals the potential otherness of the human form, which is triggered by death and through which one becomes one with nature. Reflecting upon the transformative potential of the human form, one can also think in terms of the bodily Other $^{9}$ that can, in all the discussed examples, appear

drowning and the female hair turning into the river weeds is also reminiscent of Ofelia and the symbolism of deadly feminine waters.

${ }^{9}$ Ideas about the Other of human bodies have been reflected upon by George Bataille (1989) who, by referring to an intuitive understanding of the existence of the Other of our own bodies, developed a notion of human animality (Borić 2005: 52). As Dušan Borić (2005: 52) notes, "His materialism emphasizes the 
in different shapes, and often in that of an animal. In the framework of the song from Otok, the transformations (into a fish and into other elements of nature) are triggered by death and/or ritual uncleanness, but could perhaps also be thought of as enhanced by water itself which, as a fluid without a permanent structure but capable of changing and taking on different forms, may in this context be taken as a symbol of change, transformation and endless possibilities (Chevalier and Gheerbrant 1983: 775).

\section{WEREWOLVES AND ANIMALITY}

The complex relationship between the body and the soul and post-mortal transformations of the human body can also be investigated in the context of Croatian folk beliefs about a specific type of supernatural beings, werewolves. Let us note that the word vukodlak "werewolf" and its diverse South and other Slavic versions (for example, vukozlak, volkolak, vovkulak, vlkodlak, etc.) is considered to derive from the Slavic *vblk: "wolf" and the South Slavic dlaka, "hair" and has first and foremost referred to a living person who can occasionally take the shape of a wolf, and, being in that form, attack people and animals (Gura and Levkievskaya 1995: 418). The word took on a different meaning through time, which can be recognised in the 19th and mid20th century South Slavic folk traditions, where it essentially refers to the so-called walking dead capable of shape shifting. It is also interesting to note that in this case the term vukodlak "werewolf" can be treated as a synonym of the term vampir "vampire", which is used to describe the same kind of a supernatural being in the Southern Slavic areas east of Croatia (Đorđević 1953: 150).

Guarding the deceased while the person is still in the house was practiced almost everywhere in Croatia. Besides honouring the deceased, the groomed dead body was kept for its believed ability to morph into supernatural, demonic beings (Grbić 1998: 298). Interestingly, this transformation could be caused by a specific animal; i.e. its presence in the vicinity of the body or its specific physical movement, such as jumping over the dead body, walking underneath the catafalque or the bier on which the deceased will be carried. The most common belief was that the dead body, if not guarded, could transform into a werewolf if a dog or a cat, in certain places a rooster as well,

continuity of existence, imposing a limit to its comprehension, in which human birth and sense of identity is a violent separation from the continuous flow of matter - from the 'state of perfect immanence"'. Battaile (1989: 23-24) sees the animal world as that of immanence and immediacy, one from which humans are separated and are unable to transcend. Although animals are not entirely autonomous in relation to the rest of the world, there is still a continuity between them and the world, in which they exists "like water in water" (Battaile 1989: 19, 24-25). 
should jump over or walk under it, for example: "No cat or dog should be in the room, because if it should jump over the deceased person, he would turn into a werewolf" (Lukić 1995: 89); "Cats and dogs are closed up, because if they go under him, he will turn into a werewolf" (Lovretić 1990: 380). It seems that while the dead human body rests in the liminal phase, not being a part of the world of the living anymore but still not integrated with the world of the dead, the animal can affect the destabilization of its identity, influence the incarnation of the human being and its post-mortal manifestation.

According to Croatian folk beliefs and stories, an animal does not only cause the transformation, but werewolves as the demonic walking dead can often act in the physical form of an animal such as a hen, a goose, a horse, a dog, a pig, a bull, a frog, a goat, and a donkey. As Vladimir Ardalić recorded about beliefs in the Dalmatian hinterland: "Werewolves turn into donkeys, fat white horses, black oxen, cats and dogs, and into green goats as the devils do" (Ardalić 1908: 150). Similar beliefs have been recorded in Kastav as well, e.g. "people in Kastav believe that werewolves turn into a horse, a frog..." (Milčetić 1896: 225) or in Kotari in Dalmatia: "A werewolf appears in the shape of the human being or an animal (dog, goat, donkey, horse, cat)" (Zorić 1896: 226). Theriomorphic characteristics become part of the bodily identity of a werewolf; they appear as the possible Other of the transformed human body. According to some stories even if a werewolf appears in the form of a human being, it can turn into an animal after being killed, which might indicate that the werewolf possessed an alter ego of his own in the form of an animal that dies together with him. ${ }^{10}$

Werewolves can also appear in the form of a human being or a shape that resembles the human body but is clearly marked as different, such as a blown up body without flesh and bones, or just a skin filled only by blood, when they are often accompanied by an animal. ${ }^{11}$ Some stories even link animals with the genealogy of the specific characteristics of the bodily image of werewolves. According to a story recorded in Poljica in Dalmatia.

A white ox and a black pig visit the graves at midnight. The ox uses its horns to move the tombstones and the pigs sniff the earth in order to find out whether the deceased is a potential werewolf. When they come upon such a deceased,

\footnotetext{
${ }^{10}$ See a story recorded by Lovretić in the village Otok in Slavonia (Lovretić 1990: 545).

${ }^{11}$ For example, a folk story from Dalmatia describes a werewolf riding a white horse: "On that same night Pava Vuković was fishing from the shore. He heard a noise on the Duboka, but the sea was calm, as calm as a mirror. At first, he thought he must have heard wrong. But then again there was a terrible noise, such that he started shivering. He got scared, it must be a werewolf, so he ran to Krilo, when suddenly, a man on a white horse flew past him splashing, as if the entire emperor's army was going by. They say it was Gruja the werewolf, going from place to place to scare people" (Ivanišević 1989: 582), (free transl). As Maja Bošković-Stulli (1993: 313) recorded in the area near the Neretva river in Croatia, a werewolf would enter the house on a horse.
} 
they pick him up from the grave, shake away his bones, blow up his body and turn him into a werewolf. (Ivanišević 1987: 583)

In addition to being turned into a werewolf by particular acts of certain animals, a person could become a werewolf if they were evil during their lifetime and/or because of the uncleanliness of the deceased (such as those who committed suicide, those who were not baptized or did not get a proper burial) (Grbić 1998: 298). Werewolves are usually active at night, they are seen in their former community, visiting their village, scaring people and making noise. The reasons for their reappearance are frequently unsettled accounts with the members of their family or the wider community. The supernatural being asks for redemption and the community is asked to pay the debts of the deceased or to pay for a holy mass. If the villagers do as asked, the deceased receives deliverance and stops appearing and disturbing the community.

The data at hand does not particularly mention whether it is the body or the soul of the human being that undergoes the transformation into the supernatural being. Authors from the wider South Slavic region that looked into the phenomena of werewolves suggest a stronger link with the human soul, proposing that a werewolf (or a vampire in Serbia) is an incarnation of the soul of a dead person (Čajkanović 1941: 19-20; Blagojević 1974: 384) while Popov (2002: 322-323) adds a note of morality to the soul's incarnation motives. Ljubinko Radenković (1999: 225) even stated that in comparison to humans who possess the dyadic category of the body and soul, a demonic body is in fact only a part of a soul. However, as is clear from this, werewolves are in certain ways still strongly linked with corporeality and physical form. As Dušan Bandić (1980: 106) noted, beliefs about werewolves are actually beliefs about dead people getting out of their graves, about dead bodies living on although in a slightly altered form. Nevertheless, the physical existence of werewolves in South Slavic folk traditions is also related with ideas about the soul which, because of specific reasons such as sinfulness or uncleanness of the deceased, does not leave the body after death but stays with it for a certain amount of time and revives into different bodily shapes (Đorđević 1953: 164). Perhaps ideas about werewolves that closely interconnect the soul and the body could be observed through the concept of the Double emphasized by Claude Lecouteux (2003) and investigated by other authors. According to these ideas, human beings have a Double that is not only spiritual but also potentially physical (Boyer 2003: ix-x). According to Lecouteux the material Double, liberated by death, is the one who has the power to take on an animal presence or to keep its human form, and is precisely what gets out of the grave and wanders around, continuing to 
live as long as the person's body has not completely decomposed (Lecouteux 2003: 147-149, xxiv).

Concepts of werewolves found in Croatian folk culture beliefs and stories can also be seen as referring to the human form not being a fixed category. Transformations triggered by death are demonized, located in the realm of the night and more often than not linked to immorality. In addition to death and the immorality of an individual, it is the animal that affects the destabilization of the human identity, which in this case places animals in opposition to humans as the Other. The awareness of the animal Other and the possibility of the transformation of human materiality, which also affects the immaterial life force, or according to certain beliefs, was affected by the "sinfulness of the soul", is present but underlined as unwanted, feared and something that should be redeemed. The unfavourable relation of humans to supernatural beings indicates a fear of changes brought by death and gives the theriomorphic symbol negative connotations.

\section{CONCLUSION}

The beliefs about the changes human beings can undergo after death found in different Croatian folk culture practices discussed in this paper relate to the transformative potential of the human body and everything it holds within. They can also be related to the notions of potential otherness of the human form which, apart from being triggered by death, seems to be linked with (im)morality of a person during lifetime or the ritual (un)cleanliness of the deceased. Sometimes the otherness of the human form is expressed through the form of an animal and as such it comes into existence only through the experience of death, in the domain of the hereafter as opposed to the sphere of the living. The folk songs discussed in the paper reveal transformations manifested through the notion of water as the liminal sphere between the world of the living and the world of the dead, where the animal symbol is represented by a fish. However, the animal does not only stand for the potential otherness of the human form but, as revealed in folk beliefs about werewolves, animals can also affect the destabilization of the human bodily identity and influence the incarnation of a human being, as well as be linked to the origination of the other physical manifestations werewolves can display. Sometimes post-mortal transformations seem to be more clearly related to the possible otherness of the human body. Nevertheless, since the body can also be perceived as the barrier of the soul, the transformations of the body by death influence the transformations or the translocations of the vital energy, the soul or, as Lecouteux (2003: 2) stated, "the immortal part 
of an individual, the link connecting one person to the entire cosmos". This point can be related to the folk song from Otok, where the connection with the "entire cosmos" can be sensed through the changes of the human form and/or possible soul translocations into water, plants and animals.

\section{REFRENCES CITED}

Ardalić, Vladimir. 1908. "Vukodlak. (Bukovica u Dalmaciji)”. Zbornik za narodni život i običaje Južnih Slavena 13/1: 148-54.

Bandić, Dušan. 1980. Tabu u tradicionalnoj kulturi Srba. Beograd: Beogradski izdavačkografički zavod.

Bataille, George. 1989. Theory of Religion. New York: Zone Books.

Blagojević, Natalija. 1974. "Vuk u narodnim običajima i verovanjima u užičkom kraju". Užički zbornik 7: 375-404.

Borić, Dušan. 2005. "Body Metamorphosis and Animality. Volatile Bodies and Boulder Artworks from Lepenski Vir". Cambridge Archaeological Journal 1/51: 35-69.

Bošković-Stulli, Maja. 1993. Žito posred mora. Usmene priče iz Dalmacije. Split: Književni krug.

Boyer, Régis. 2003. "Foreword". In Witches, Werewolves and Fairies. Shapeshiters and Astral Doublers in the Middle Ages. Claude Lecouteux. Rochester: Inner Traditions, vii-xi.

Broz, Ivan and Stjepan Bosanac, eds. 1896. Hrvatske narodne pjesme, 1. Zagreb: Matica hrvatska.

Chevalier, Jean and Alan Gheebrant, eds. 1983. Rječnik simbola. Mitovi, snovi, običaji, geste, oblici, likovi, boje, brojevi. Zagreb: Nakladni zavod Matice hrvatske.

Čajkanović, Veselin. 1941. O srpskom vrhovnom bogu. Beograd: Srpska kraljevska akademija, Zadužbina Milana Kujundžića.

Davies, Douglas James. 2005. A Brief History of Death. Oxford: Blackwell Publishing.

Durand, Gilbert. 1991. Antropološke strukture imaginarnog. Zagreb: August Cesarec.

Đorđević, Tihomir. 1953. "Vampir i druga bića u našem narodnom verovanju i predanju”. Srpski etnografski zbornik 30: 147-282.

Franković, Đuro, ed. 2004. Sanak snila budimska kraljica - epske pjesme i balade. Pečuh/Pécs: Frankovics és Társa Kiadói Bt.

Grbić, Jadranka. 1998. “Predodžbe o životu i svijetu”. In Etnografija. Svagdan i blagdan hrvatskog puka. Jasna Čapo Žmegač et al., eds. Zagreb: Matica hrvatska, 296-336.

Gura, Aleksandr Viktorovič and Elena Evgenevna Levkievskaya. 1995. "Volkolak". In Ethnoliguistic dictionary Slavjanskie drevnosti, 1. Nikita I. Tolstoy, ed. Moskva, 418-420.

Henderson, Joseph Lewis. 1973. "Drevni mitovi i suvremeni čovjek”. In Čovjek i njegovi simboli. Karl G. Jung, ed. Zagreb: Mladost, 104-157.

Ivanišević, Frano. 1987. Poljica. Narodni život i običaji. Split: Književni krug.

Jovanović, Bojan. 2001. Magija srpskih rituala. Niš: Prosveta.

Karadžić, Vuk Stefanović. 1965. Srpske narodne poslovice. Beograd: Prosveta.

Kulišić, Špiro et al., eds. 1970. Srpski mitološki rečnik. Beograd: Nolit.

Kumer, Zmaga et al., eds. 1970. Slovenske ljudske pesmi, 1. Ljubljana: Slovenska matica. 
Lecouteux, Claude. 2003. Witches, Werewolves and Fairies. Shapeshiters and Astral Doublers in the Middle Ages. Rochester: Inner Traditions.

Lovretić, Josip. 1990. Otok. Narodni život i običaji. Vinkovci: Kulturni informativni centar Privlačica.

Lukić, Luka. 1995. Varoš. Narodni život i običaji, 2. Slavonski Brod: Matica hrvatska, Ogranak Slavonski Brod.

Marjanić, Suzana. 2004. “Južnoslavenske folklorne koncepcije drugotvorenja duše i zoopsihonavigacije/zoometempsihoze". Kodovi slovenskih kultura 9: 208-248.

Marjanić, Suzana. 2004a. "Životinjsko u vilinskom”. In Između roda i naroda. Etnološke i folkloritičke studije. Renata Jambrešić Kirin and Tea Škokić, eds. Zagreb: Institut za etnologiju i folkloristiku, Centar za ženske studije, 231-256.

Marjanić, Suzana. 2011. “Duša kao postmortalna ptica. Južno/slavenske folklorne predodžbe o duši-ptici i/ili ptici-duši". In Ptice, književnost, kultura. Dragan Bošković and Mirjana Detelić, eds. Kragujevac: Centar za naučna istraživanja SANU i Univerziteta, 27-50.

Marjanić, Suzana. 2012. "The Mythical Cyborg of Croatian Oral Legends and the Fantasy Genre". Studia mythologica Slavica 14: 87-106.

Mencej, Mirjam. 1995. “Duša umrlega kot živali pri starih Slovanih”. Anthropos 5-6: 198-212.

Mencej, Mirjam. 1997. Voda v predstavah starih slovanov o posmrtnem življenju i šegah ob smrti. Ljubljana: Slovensko etnološko društvo.

Milčetić, Ivan. 1896. "Vjera u osobita bića. 1. Vukodlak i krsnik. b) Krk i Kastav u Istri”. Zbornik za narodni život i običaje Južnih Slavena 1: 224-226.

Petrović, Sreten. 1999. Srpska mitologija, 1. Sistem srpske mitologije. Niš: Prosveta.

Popov, Račko. 2002. “Зооторфният коิд в погребалните представи на Българите”. Običaji životnoga ciklusa. Beograd: Etnografski institut SANU, 321-327.

Radenković, Ljubinko. 1996. Simbolika sveta u narodnoj magiji Južnih Slovena. Niš: Prosveta.

Radenković, Ljubinko. 1999. "Ljudsko i neljudsko u izgledu mitoloških bića”. Kodovi slovenskih kultura 4: 220-227.

Shilling, Chris. 2003. The Body and Social Theory [second edition]. London: Sage.

Šešo, Luka. 2007. "Vjerovanja u biča koja se pretvaraju u životinje”. In Kulturni bestijarij. Suzana Marjanić and Antonija Zaradija Kiš, eds. Zagreb: Hrvatska sveučilišna naklada, Institut za etnologiju i folkloristiku, 253-275.

Širola, Božidar, ed. 1942. Hrvatska pjesmarica. Rodoljubne, narodne, umjetničke i društvene popijevke s notama za jedan glas. Zagreb: Tisak narodne tiskare.

Štrekelj, Karl, ed. 1980. Slovenske narodne pesmi, 1. Ljubljana: Slovenska matica.

Thompson, Stith, ed. 1956. Motif-Index of Folk-Literature. A Classification of Narrative Elements in Folktales, Ballads, Myths, Fables, Medieval Romances, Exampla, Fabliaux, Jest-Books, and Local Legends, 2. D-E. Copenhagen: Rosenklide and Bagger.

Zorić, Mate. 1896. “Vjera u osobita bića. 1. Vukodlak i krsnik. b) Kotari u Dalmaciji”. Zbornik za narodni život i običaje Južnih Slavena 1: 226-226.

Vinogradova, Lyudmila Nikolaevna. 2001. "Voda". In Slovenska mitologija. Enciklopedijski rječnik. Svetlana M. Tolstaya and Ljubinko Radenković, eds. Beograd: Zepter Book World, 87-88.

Vukanović, Tatomir. 1986. Srbi na Kosovu, 2. Tradicionalna kultura. Vranje: Nova Jugoslavija.

Zečević, Slobodan. 1982. Kult mrtvih kod Srba. Beograd: Vuk Karadžić, Etnografski muzej. 


\title{
TIJELO, DUŠA I ŽIVOTINJSKI DRUGI
}

\begin{abstract}
SAŽETAK
U radu se razmatraju preobrazbe kojima je nakon smrti podložno ljudsko tijelo na primjerima pojedinih vjerovanja i praksi hrvatske tradicijske kulture. Smrt potiče propitivanje stabilnosti ljudskoga lika, njegovu potencijalnu drugost te granice između životinjskog i ljudskog. Analizirane usmene pjesme na kojima se rad temelji upućuju na predodžbu o vodi kao liminalnoj sferi između svijeta živih i svijeta mrtvih, a animalni simbol - riba - moguće da je povezan s idejom o posmrtnom postojanju ljudske duše. Sljedeći razmatrani korpus tekstova o vjerovanju u vukodlake, nadnaravna bića u koja se čovjek najčešće može preobraziti nakon smrti, otkriva predodžbe o životinjama kao potencijalnom Drugom. One mogu utjecati na preobrazbu ljudskog lika nakon smrti ili ga čak i utjeloviti u sferi nadnaravnog. Ipak, u sagledanim južnoslavenskim poimanjima o mogućim postmortalnim pretvorbama ljudskih bića, njihovih tijela i/ili duša, životinja ne figurira samo kao potencijalna drugost ljudskog lika već njenim posredstvom dolazi do destabilizacije ljudskog tjelesnog identiteta, transgresije njegovih granica te povezivanja besmrtne duše s prirodnim svijetom.
\end{abstract}

Ključne riječi: tijelo, duša, smrt, životinjsko, preobrazbe 